\title{
Breeding Progress for Grain Yield and Yield Related Characters of Kabuli Chickpea (Cicer arietinum L.) in Ethiopia Using Regression Analysis
}

\author{
Megersa Tadesse ${ }^{1,2}$, Assefa Funga ${ }^{2,3}$, Asnake Fikre ${ }^{4}$, Tulu Degefu ${ }^{5}$, Million Eshete ${ }^{3}$, Lijalem Korbu ${ }^{3}$, \\ Nigussie Girma ${ }^{3}$, Dagnachew Bekele ${ }^{3}$, Ridwan Mohamed ${ }^{3}$, Zewdie Bishaw ${ }^{6}$, Pooran Gaur ${ }^{7} \&$ Chris O. Ojiewo ${ }^{8}$ \\ ${ }^{1}$ Department of Statistics, Jimma University, Ethiopia \\ ${ }^{2}$ Department of Horticulture, Jomo Kenyatta University of Agriculture and Technology, Nairobi, Kenya \\ ${ }^{3}$ Ethiopian Institute of Agricultural Research, Debre-Zeit Agricultural Research Center, Debre Zeit, Ethiopia \\ ${ }^{4}$ International Crops Research Institute for Semi-Arid Tropics (ICRISAT), Addis Ababa, Ethiopia \\ ${ }^{5}$ Applied Biology Program, Adama Science and Technology University, Adama, Ethiopia \\ ${ }^{6}$ International Center for Agricultural Research in the Dry Areas (ICARDA), Addis Ababa, Ethiopia \\ ${ }^{7}$ International Crops Research Institute for Semi-Arid Tropics, Patancheru, Hyderabad, Telangana, India \\ ${ }^{8}$ International Crops Research Institute for Semi-Arid Tropics (ICRISAT), Nairobi, Kenya \\ Correspondence: Chris O. Ojiewo, International Crops Research Institute for Semi-Arid Tropics, Box 39063, \\ Nairobi, Kenya. Tel: 254-20-722-4550. E-mail: c.ojiewo@cgiar.org
}

Received: October 16, 2017

doi:10.5539/jas.v10n2p195
Accepted: December 5, 2017 Online Published: January 15, 2018

URL: https://doi.org/10.5539/jas.v10n2p195

\begin{abstract}
The genetic progress in seed yield and yield related characters of 10 kabuli chickpea varieties released by the Ethiopian Chickpea Crop Improvement Program from 1974 to 2017 was assessed during the main cropping season. The varieties were evaluated in the Randomized Complete Block design at Debrezeit Agricultural Research Center experimental research farm. The overall increase in seed yield over the local check, DZ-10-4, was estimated to be $739 \mathrm{~kg} / \mathrm{ha}$ (38.9\%). On station grain yield increased from 1900 to $3250 \mathrm{~kg} / \mathrm{ha}$ during the last 43 years and the overall increase in seed yield of the Arerti variety over the oldest variety DZ-10-4 was estimated to be $1350 \mathrm{~kg} / \mathrm{ha}$ or $71.1 \%$. Based on the regression analysis, the estimated average annual rate of increase in grain yield potential was $10.87 \mathrm{~kg} / \mathrm{ha} /$ year with an annual relative genetic change of $0.57 \% /$ year. Genotypic change was an important source for increased grain yield potential during the studied period. Positive genetic gains were observed for the yield traits (grain yield and yield components). The average cumulative gains over 43 years of breeding was, therefore, $445.67 \mathrm{~kg}(23.37 \%)$ for seed yield, and $30.26 \mathrm{~g}$ for hundred seeds weight (297.7\%). Hundred seed weight revealed the most dramatic response to breeding for the last 43 years. It is, therefore, strategically advisable that breeding efforts in the future should give due attention to yield related traits of kabuli chickpea varieties.
\end{abstract}

Keywords: chickpea, kabuli, regression, relative genetic gain, yield potential

\section{Introduction}

Chickpea, an important grain legume crop, is grown in over 50 countries of the world in diverse agroecological conditions. Among grain legumes, it acquires fourth position based on both cultivated area and production in the world (FAOSTAT, 2014). It is an excellent source of protein and carbohydrate and its protein is of high quality as compared to other pulse crops (Ercan et al., 1995). The average seed yield of chickpea in Ethiopia is 1.91 tons/ha. The total land coverage and yield of chickpea in Ethiopia are estimated to be 225607.53 hectares and 444145.93 tons, respectively (CSA, 2017).

The crop has a great economic merit in Ethiopia providing a cheap source of protein for human diet and animal feed, and as a source of alternative cash income to the farmers and foreign currency to the country. Despite its high economic importance, the national average yield of chickpea is still lower (at $1.97 \mathrm{t} / \mathrm{ha}$; CSA, 2017) than its 
potential of up to $5 \mathrm{t} / \mathrm{ha}$. Chickpea yields are limited by factors such as pests, diseases, drought and yield improvement requires compatible resilient varieties adapted to different agro-ecological zones.

Chickpea breeding in Ethiopia was started in the 1970's with the prime objectives of improving seed yield, seed size and resistance to important diseases, particularly fusarium wilt and aschocyta blight. From thebreeding efforts in Ethiopia, a number of improved chickpea varieties have been developed and released for production under different recommendation domains, including the mid and high altitude agro-ecologies and the waterlogged vertisol areas. For the last 43 years of Kabuli type chickpea improvement, grain yields and hundred seed weight (seed size) showed significant increment. Breeding efforts on kabuli type chickpea to improve its yield was relatively less prominent probably owing to stringent international grain quality requirements.

Systematic research in the country on Kabuli type chickpea commenced in the 1970s. Since then, several efforts have been made to identify and address its major production constraints. Accordingly, prevalence of diseases, insect pests, absence or limited use of modern inputs and inappropriate agronomic practices were found to be constraints of chickpea productivity. Furthermore, progress in chickpea breeding in the country has also been constrained by lack of good early maturing variety with ability to resist known chickpea diseases. Understanding the amount of genetic gain realized through past crop breeding efforts is absolutely essential to improving the efficiency and effectiveness of future breeding endeavors (Evans, 1993; Ustun et al., 2001; Waddington et al., 1987). Besides quantifying the progress obtained in a certain period, the genetic gain analysis also enables aggregation of other information, such as comparison of the gains obtained with the use of different breeding strategies or in different environments (Specht \& Williams, 1984). This kind of information contributes to the understanding of past events, allows elaboration of new strategies, adoption of corrective methods and more efficient resource allocation that together result in an increase in the breeding programs efficacy.

The efficiency of a plant breeding program is measured by progress made when the average genetic value of the offspring is higher than the average genetic value of the previous generation. The accurate estimation of genetic progress realized from long-term breeding efforts is a difficult task but various procedures may be used. Among the available procedures, the performance of genotypes in common environments regressed over years of varietal release of a given crop as a continuous quantitative variable provided the most direct estimate of genetic gain from breeding and has widely been used in different crops (Cox et al., 1988). For example, genetic progresses using the same procedure were reported in barley (Martintello et al., 1987), groundnut (Mozingo et al., 1987), sunflower (Pereira et al., 1999), wheat (Brancourt-Hulmel et al., 2003; Parveen \& Khalil, 2011; Rodrigues et al., 2007; Shearman et al., 2005), soybean (Jin et al., 2010; Liu et al., 2012; Morrison et al., 2000; Ustun et al., 2001) and maize (Luque et al., 2006).

Genetic progress made over time from breeding of different crops in Ethiopia have also been studied using the same procedure and documented in haricot bean (Bezawuletaw et al., 2006), maize (Worku \& Zelleke, 2007), barley (Fekadu et al., 2011), groundnut (Hagos et al., 2012) and faba bean (Tolessa et al., 2015). The magnitude of genetic progress of chickpea for hundred seed weight and grain yield in association with changes in resistance to adzuki bean beetle (Callosobruchus chinensis) was reported (Keneni et al., 2011). In recent years more studies on genetic progress made over time from breeding chickpea in Ethiopia have been reported (Belete et al., 2013, 2016). The purpose of present study was to update the estimates of genetic progress made over-time in seed yield and yield related traits of kabuli chickpea, taking account of recent variety releases.

\section{Materials and Methods}

The experiment was conducted at the experimental field of Debre Zeit Agricultural Research Center (DZARC). The center is located at $8^{\circ} 44^{\prime} \mathrm{N}$ latitude and $38^{\circ} 58^{\prime} \mathrm{E}$ longitude at an altitude of $1900 \mathrm{~m}$.a.s.l. Ten kabuli chickpea varieties,released between 1974 and 2017, were used (Table 1). The experiment was set using randomized complete block design with three replications. Each gross plot size was $4.8 \mathrm{~m}^{2}$ and consisted of 4 rows of $4 \mathrm{~m}$ in length. The two middle-rows, with net plot of $2.4 \mathrm{~m}^{2}$, were considered in recording data. The spacing between rows and between plants within row was $30 \mathrm{~cm}$ and $10 \mathrm{~cm}$, respectively. Pesticides were also applied to control major diseases and insects. Hand weeding was practiced as frequently as needed. Data were recorded on days to $50 \%$ flowering, maturity, plant height $(\mathrm{cm})$, hundred seed weight $(\mathrm{g})$ and seed yield $(\mathrm{kg} / \mathrm{ha})$. To estimate the annual genetic gain achieved in seed yield and changes produced on associated agronomic traits, the mean values of each character for each variety were regressed against the year of release. The year of release was expressed as the number of years since 1974, the period when coordinated chickpea improvement program started. 
Table 1. Description of the 10 kabuli chickpea varieties used in the experiments

\begin{tabular}{lllllll}
\hline No & Name of Variety & Pedigree & Year of release & Source & Seed rate & $\begin{array}{l}\text { Recommendation } \\
\text { domain (m.a.s.1.) }\end{array}$ \\
\hline 1 & DZ-10-4 & DZ-10-4 & 1974 & Selection & $65-75$ & $1800-2300$ \\
2 & Shasho & ICCV-93512 & 1999 & Hybridization & $100-125$ & $1800-2600$ \\
3 & Arerti & FLIP 89-84c & 1999 & Hybridization & $110-115$ & $1900-2600$ \\
4 & Chefe & ICCV-92318 & 2004 & Hybridization & $110-140$ & $1800-2000$ \\
5 & Habru & FLIP 88-42C & 2004 & Hybridization & $110-140$ & $1800-2600$ \\
6 & Ejere & FLIP 92-263c & 2005 & Hybridization & $120-140$ & $1800-2600$ \\
7 & Teji & FLIP 97-266C & 2005 & Hybridization & $120-140$ & $1800-2700$ \\
8 & Monino & ACOS DUBIE & 2006 & Introduction & $150-160$ & $1600-2400$ \\
9 & Hora & FLIP 04-9C & 2017 & Hybridization & $130-140$ & $1800-2600$ \\
10 & Dhera & FLIP 0163 & 2017 & Hybridization & $130-140$ & $1800-2800$ \\
\hline
\end{tabular}

\subsection{Statistical Analysis}

Genetic gain of grain yield was estimated from the trials "Final Assessment of kabuli chickpea lines and Cultivars" conducted between the 1974 and the 2017 growing seasons, at several locations. Linear regression analysis was used to calculate the genetic gain for each trait considered in the study. The breeding effect was estimated as a genetic gain for grain yield and associated traits in chickpea improvement by regressing mean of each character for each variety against the year of release of that variety. The magnitude of genetic progress from breeding was estimated by regressing the mean performances of the genotypes on years of varietal release using 1974, when the first variety was released, as the base year (Cox et al., 1988). The linear relationship between a dependent variable $\mathrm{Y}$ and independent variable $\mathrm{X}$ is represented by the equation:

$$
\mathrm{Y}=\mathrm{a}+\mathrm{bx}+\mathrm{e}
$$

where, $\mathrm{Y}=$ the mean value of the dependent variable, $\mathrm{x}=$ the mean value of the independent variable, $\mathrm{a}=$ the intercept of the line, $\mathrm{e}=$ error term and $\mathrm{b}=$ the regression coefficient (slope of the line), or the changes in $y$ per unit change in $x$.

A straight line was fitted through the points using simple linear regression and the resultant coefficients of regression of genotype mean performances on the years of varietal release were used as estimates of the annual genetic progress calculated as:

$$
\text { Annual rate of gain }(b)=\frac{\operatorname{Cov}(X, Y)}{\operatorname{Var}(X)}
$$

where, $\mathrm{X}=$ the year of variety release, $\mathrm{Y}=$ the mean value of each character for each variety, $\mathrm{Cov}(\mathrm{X}, \mathrm{Y})=$ the covariance of $\mathrm{X}$ and $\mathrm{Y}$; and $\operatorname{Var}(\mathrm{X})=$ the variances of $\mathrm{X}$.

The relative annual gain achieved over the last 43 years (1974-2017) for Kabuli chickpea was determined as a ratio of genetic gain to the corresponding mean value of oldest variety and expressed as percentage. Simple linear relationship among all characters were calculated using means of each character. Correlation coefficients for the traits under consideration were computed using means of varieties. Correlation coefficient between $\mathrm{Y}$ and $\mathrm{X}$ was computed as:

$$
r_{\mathrm{xy}}=\frac{\operatorname{Cov}(\mathrm{X}, \mathrm{Y})}{\sqrt{\operatorname{Var}(\mathrm{X}) \cdot \operatorname{Var}(\mathrm{Y})}}
$$

where, $\operatorname{Cov}(\mathrm{X}, \mathrm{Y})=$ Covariance between $\mathrm{X}$ and $\mathrm{Y}, \operatorname{Var}(\mathrm{X})=$ Variance of $\mathrm{X}$ and $\operatorname{Var}(\mathrm{Y})=$ Variance of $\mathrm{Y}$.

The data were analyzed using the $\mathrm{R}$ software version 2.15.2.

\section{Results and Discussions}

The mean values for grain yield ranged from 1900 to $3400 \mathrm{~kg} / \mathrm{ha}$ with an average yield of $2650 \mathrm{~kg} / \mathrm{ha}$ on station. Table 2 shows the mean seed yield of varieties released in 1974, 1999, 2004, 2005, 2006 and 2017. The least and highest increases were $325 \mathrm{~kg} / \mathrm{ha}(18.4 \%)$ and $1350 \mathrm{~kg} / \mathrm{ha}(71.1 \%)$ for the varieties released in 2006 and Arerti variety, respectively, over the local check, DZ-10-4. The overall increase in grain yield over the local variety was estimated to be $857.14 \mathrm{~kg} / \mathrm{ha}(45.11 \%)$ considering all varieties in the trial (Table 2). Hence, grain yield increased substantially with the release of improved varieties. This was in agreement with other findings on soybean (Karmakar \& Bhatanagar, 1996), which reported a significant increase in grain yield of new soybean cultivars over the older ones. It was also reported that the average grain yield of soybean ranged from 1.117 to 
1.710 tons/ha for the period of 1980 to 1996 (Tefera et al., 2009). Furthermore in another similar study, better seed yield of new soybean cultivars over that of the first old varieties was reported (Demissew, 2010). This gives an insight for possible future opportunities to exploit the genetic potential of the crop for enhanced chickpea production.

Table 2. Mean value of traits obtained from analysis of grain yield and yield components of kabuli chickpea varieties

\begin{tabular}{|c|c|c|c|c|c|c|}
\hline \multirow[b]{2}{*}{ Variety } & \multicolumn{6}{|c|}{ Grain yield and yield components } \\
\hline & $\begin{array}{l}\text { Grain yield } \\
(\mathrm{kg} / \mathrm{ha})\end{array}$ & $\begin{array}{l}\text { Days to } \\
\text { flowering }\end{array}$ & $\begin{array}{l}\text { Days to } \\
\text { maturity }\end{array}$ & $\begin{array}{l}\text { Plant height } \\
(\mathrm{cm})\end{array}$ & $\begin{array}{l}100 \mathrm{SW} \\
(\mathrm{kg} / \mathrm{ha})\end{array}$ & $\begin{array}{l}\text { Seed rate } \\
(\mathrm{kg} / \mathrm{ha})\end{array}$ \\
\hline DZ-10-4 & 1900 & 49.50 & 123.0 & 36.90 & 10.20 & 70.00 \\
\hline Shasho & 3100 & 60.50 & 122.5 & 49.60 & 29.90 & 117.50 \\
\hline Arerti & 3400 & 58.50 & 130.0 & 45.20 & 25.70 & 107.50 \\
\hline Chefe & 2450 & 48.50 & 121.5 & 46.05 & 33.45 & 125.00 \\
\hline Habru & 2850 & 59.50 & 120.5 & 46.05 & 32.20 & 125.00 \\
\hline Ejere & 2500 & 49.00 & 123.5 & 40.00 & 37.20 & 130.00 \\
\hline Teji & 2750 & 53.50 & 126.0 & 36.60 & 38.10 & 130.00 \\
\hline Acos Dubie & 2250 & 43.00 & 121.5 & 44.00 & 64.00 & 155.00 \\
\hline Hora & 2730 & 60.5 & 133.0 & 48.05 & 31.36 & 135.00 \\
\hline Dhera & 2460 & 60.75 & 133.8 & 60.99 & 33.24 & 135.00 \\
\hline Mean & 2609.23 & 54.33 & 125.53 & 45.34 & 33.54 & 123.00 \\
\hline CV \% & 16.18 & 11.90 & 3.96 & 15.58 & 39.61 & 18.27 \\
\hline
\end{tabular}

Plotting mean grain yields of the 10 tested kabuli chickpea varieties versus the year of release (Figures 1) showed an upward trend since the mid 1970s (a year when the first improved varieties were released). The estimated average annual rates of increase in seed yield potential were $10.87 \mathrm{~kg} / \mathrm{ha} /$ year (Figure 1) for all varieties. This indicated that past kabuli chickpea breeding efforts in Ethiopia have resulted in an average grain yield increment of $445.67 \mathrm{~kg} \mathrm{ha}^{-1}$ when the local check variety, DZ-10-4, was used as a reference (Table 3). Similarly, previous work on durum wheat (Waddington et al., 1987), Australian spring wheat (Perry \& D'Antuono, 1989), soybean (Voldeng et al., 1997), and tef (Teklu, 1998) reported an increase in yield potential of the tested varieties over years of variety release.

The mean relative annual gain in grain yield of kabuli chickpea varieties since 1974 was $0.57 \%$ increase per year (39\% improvement of yield), or about $23.37 \%$ for the whole period of 43 years (Table 5). Present results indicated that the plant breeding efforts made substantial progress during the last 43 years in improving the yields of kabuli chickpea varieties in Ethiopia. Besides, there was no indication of yield potential plateau in kabuli chickpea varieties over the period of the study (Figure 1) which indicates that further improvement is possible to increase yield and this provides clues for breeders to further exploit (increase) the yield potential of the existing kabuli chickpea varieties.

Table 3. Average seed yield $(\mathrm{kg} / \mathrm{ha})$ of kabuli chickpea varieties and increment over the first released variety, DZ-10-4

\begin{tabular}{|c|c|c|c|c|c|c|c|}
\hline \multirow{2}{*}{ Name of Variety } & \multirow{2}{*}{ Year of release } & \multirow{2}{*}{$\begin{array}{l}\text { Average Seed } \\
\text { Yield }(\mathrm{Kg} / \mathrm{ha})\end{array}$} & \multicolumn{2}{|c|}{ Increment over DZ-10-4 } & \multirow{2}{*}{$\begin{array}{l}100 \text { Seed } \\
\text { Weight }(\mathrm{g})\end{array}$} & \multicolumn{2}{|c|}{ Increment over DZ-10-4 } \\
\hline & & & $\mathrm{Kg} / \mathrm{ha}$ & $\%$ & & gram & $\%$ \\
\hline DZ-10-4 & 1974 & 1900 & - & - & 10.20 & - & - \\
\hline \multicolumn{8}{|l|}{ Shasho } \\
\hline Arerti & 1999 & 3250 & 1350 & 71.1 & 27.80 & 17.6 & 172.6 \\
\hline \multicolumn{8}{|l|}{ Chefe } \\
\hline Habru & 2004 & 2650 & 750 & 39.5 & 32.83 & 22.6 & 221.9 \\
\hline \multicolumn{8}{|l|}{ Ejere } \\
\hline Teji & 2005 & 2625 & 725 & 38.2 & 37.65 & 27.5 & 269.1 \\
\hline Acos Dubie & 2006 & 2250 & 350 & 18.4 & 64.00 & 53.8 & 527.5 \\
\hline \multicolumn{8}{|l|}{ Hora } \\
\hline Dhera & 2017 & 2595 & 695 & 36.6 & 32.30 & 22.1 & 216.7 \\
\hline
\end{tabular}


The genetic progress made in seed yield $\left(0.57 \% \mathrm{ha}^{-1} \mathrm{year}^{-1}\right)$ from kabuli chickpea breeding in Ethiopia is much lower than the progress made in seed yields from breeding of other crops like barley $\left(1.34 \% \mathrm{ha}^{-1}\right.$ year $\left.^{-1}\right)$ (Fekadu et al., 2011), groundnut $\left(1.89 \% \mathrm{ha}^{-1}\right.$ year $\left.^{-1}\right)$ (Hagos et al., 2012) and haricot bean $\left(3.24 \% \mathrm{ha}^{-1}\right.$ year $\left.^{-1}\right)$ (Bezawuletaw et al., 2006) and higher than faba been $\left(0.26 \% \mathrm{ha}^{-1}\right.$ year $\left.^{-1}\right)$ (Tolessa et al., 2015). In other countries, reports also revealed higher annual yield increases of $0.58 \% \mathrm{ha}^{-1} \mathrm{year}^{-1}$ from breeding soybean in Northeast China (Jin et al., 2010), 0.45\% ha ${ }^{-1}$ year $^{-1}$ from breeding soybean in Canada (Morrison et al., 2000) and 0.39\% $\mathrm{ha}^{-1}$ year ${ }^{-1}$ from hundred years of barley breeding in England (Riggs et al., 1981). Even though genetic gain in grain yield from chickpea breeding in Ethiopia indicate the progress, the progress made was lower than other crops and the actual yield is also lower than potential yield. Bekele et al. (2016) associated this low marginal genetic gain in grain yield to the increase in seed size. Chickpea seed yield increases as seed size increases up to an optimum (normally 50-55 g/100 seed weight) beyond which the yield reaches a plateau and actually starts reducing and large-seeded kabuli typeshave been reported to produce a lower yield than the small-seeded kabuli cultivars (Gowder et al., 2010). In this particular study, the variety Monino with 100 seed weight of $64 \mathrm{~g}$ could be responsible for significantly bringing down the mean genetic gains.

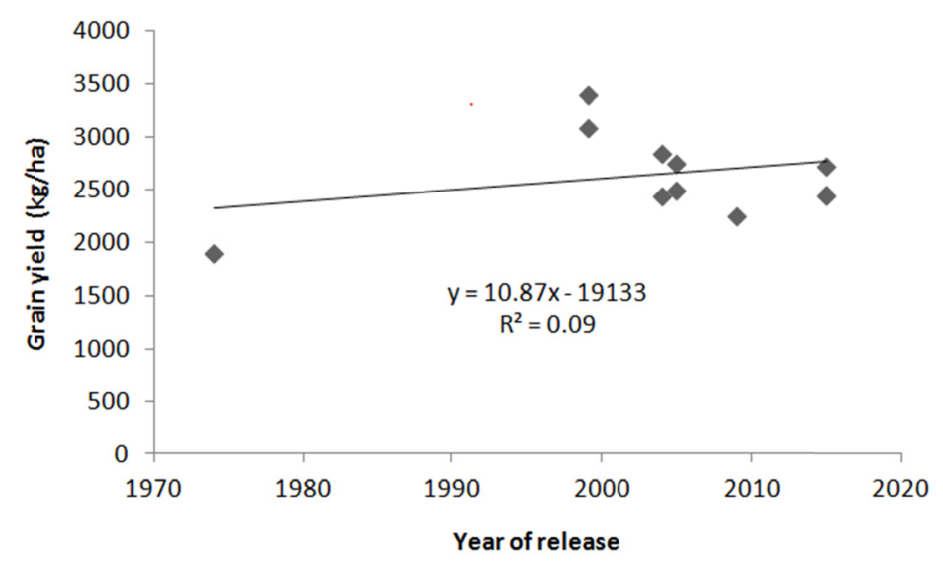

Figure 1. Association between mean seed yield of 10 kabuli chickpea varieties and the year of release since 1974 (the year when coordinated kabuli chickpea improvement program started)

The 100 seed weight levels varied significantly from 10.2 to 64 grams among the 10 varieties (Table 2). Regression analysis revealed that a positive association and significant trend between mean 100 seed weight and years of varietal releases (Figure 2), which was in contrary with finding from soybean reported earlier in Canada (Voldeng et al., 1997). The annual rate of genetic progress from breeding kabuli chickpea was estimated to be

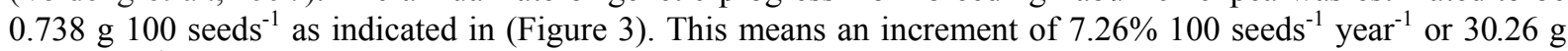
100 seeds $^{-1}(297.7 \%)$ during four decades of breeding period over the oldest variety, DZ-10-4. Better genetic progress was obtained from breeding kabuli chickpea for 100 seed weight than it was for seed yield. One hundred seed weight was also significantly affected with the release of improved varieties. Similarly, a significant annual increase in a hundred seed weight occurred in USA in all the maturity groups of soybean released during the period 1902 to 1977 (Specht \& Williams, 1984). Based on the relative comparison of different varieties for the temporal changes made through breeding, 172.6-527.5\% hundred seed weight increment was obtained for kabuli chickpea varieties when compared with reference variety, DZ-10-4 (Table 3). Similar findings with more increments in 100 seed weight than in seed yield, was also reported from chickpea breeding in Ethiopia (Keneni et al., 2011; Tolessa et al., 2015; Bekele et al., 2016). This could be attributed to the fact that, while seed yield is the primary character of interest and a prime objective in most of the Ethiopian crop breeding programs for the last many decades, hundred seed weight/seed size has received a special attention in the recent past both at national and international levels, in response to the current move towards meeting the export-market demand for large seed size (EARO, 2000). 


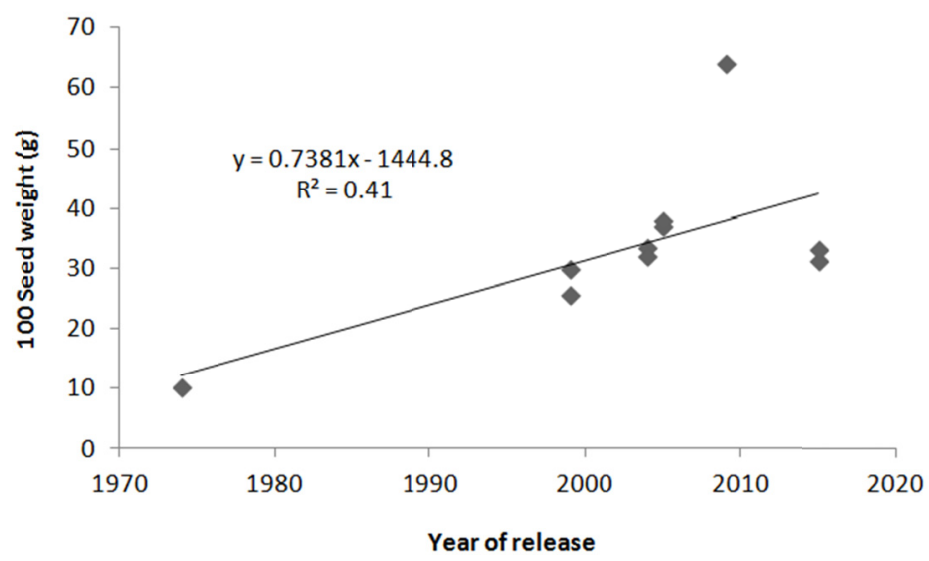

Figure 2. Scatter plot of 100 seed weight (g) against years of variety release from 1974 to 2017

Table 4. Estimation of mean values, coefficient of determination $\left(\mathrm{R}^{2}\right)$ and regression coefficients (b) of some yield attributes against the year of release of varieties

\begin{tabular}{lllll}
\hline Character & Mean (1974) & Mean (1974-2015) & $\mathrm{R}^{2}$ & $\mathrm{~b}$ \\
\hline Grain yield & 1900 & 2639.00 & - & 10.87 \\
Days to flowering & 49.5 & 54.33 & 0.06 & 0.14 \\
Days to maturity & 123 & 125.53 & 0.18 & 0.18 \\
Plant height & 36.9 & 45.34 & 0.32 & 0.34 \\
100 seed weight & 10.2 & 33.54 & 0.41 & $0.74^{* *}$ \\
\hline
\end{tabular}

Note. $* *=$ Significant at $5 \%$ level.

The mean rate of increase in total grain yield per year of release, estimated from the slope of the graph was 10.87 (Figure 1). The relative annual gains of grain yield was $0.57 \%$ over the 43 years (Table 5), indicating that genetic improvement for this trait was important for seed yield enhancement in kabuli chickpea varieties during the study period.

Table 5. The annual relative genetic gain and correlation coefficients for grain yield and yield contributing traits of kabuli chickpea varieties

\begin{tabular}{lll}
\hline Character & Relative genetic gain $\left(\%\right.$ year $\left.^{-1}\right)$ & Correlation Coefficient $(\mathrm{r})$ \\
\hline Grain yield(kg/ha) & 0.57 & - \\
Days to flowering & 0.28 & $0.65^{* *}$ \\
Days to maturity & 0.15 & 0.25 \\
Plant height $(\mathrm{cm})$ & 0.92 & 0.22 \\
100 Seed Weight & 7.26 & -0.05 \\
\hline
\end{tabular}

Note. $* *=$ Significant at $5 \%$ level.

However, unlike other attributes, a significant relative gain per year was obtained for the 100 seed weight during the whole period of yield improvement program. There were challenges to improve the number of days to flowering, days to maturity and plant height during the given period of time (Table 5).

\subsection{Phenological Traits}

Days to flowering obtained in this study ranged from 43 to 60.75 with a mean of 51.9 (Table 2). In the present study Habru variety had the lowest number of days to flowering and the new variety, Dhera had the longest. The regression of the mean days to flowering of kabuli chickpea variety on the year of release indicated that there was 0.14 days/year average annual rate of increase (Table 6). This was not significantly different from zero, revealing that there was a non-significant improvement from the old to the modern varieties in days to flowering. The relative gain in terms of annual days to flowering in kabuli chickpea varieties was estimated to be $0.28 \%$ per 
year for the 43 years (Table 5). This low gain is mainly due to late flowering of some varieties such as Shasho, Hora and Dhera.The present result was in contrary with the results of others (Bezawuletaw et al., 2006; Hagos et al., 2012), who reported negative and insignificant regression coefficient in days to flowering of haricot bean and groundnut. This indicates that the breeding program had has not focused in the reduction of the days to flowering or release of early maturing kabuli chickpea. Days to maturity obtained in this study ranged from 120.5 to 133.8 with a mean of 127.15 (Table 2).

Like days to flowering, the regression analysis indicated a positive regression coefficient in days to maturity which was 0.18 . It can be seen from the table that there was no significant trend of increasing in days to maturity over 43 years. This insignificant increase occurred due to late flowering character of some released and proposed varieties such as Arerti, Hora and Dhera. Hence, the change in days to maturity was not associated with the year of release of the varieties. This was in agreement with the report on haricot bean varieties released in Ethiopia from 1972 to 1996 (Bezawuletaw et al., 2006). Similar results were also reported on groundnut varieties released from 1976 to 2009 (Hagos et al., 2012). However, the results from this study are different from the reports from soybean cultivars released in India from 1969 to 1993 (Karmakar \& Bhatanagar, 1996). The present study shows that kabuli chickpea varieties did not show significant differences for days to maturity over the period of the genetic improvement.

\subsection{Plant Height and Hundred Seed Weight}

In this current study, there was a non-consistent gradual increase in plant height from the older to the newer varieties. As it was estimated from regression of variety means against year of release, the annual rate of gain, $0.34 \mathrm{~cm} \mathrm{ha}^{-1}$ year $^{-1}$, was not different from zero (Table 4). This implied that yield improvement program did not significantly affect this trait. In contrast, a conspicuous reduction in plant height was reported for soybean cultivars released in India (Karmakar \& Bhatanagar, 1996).

Since 1974, the relative annual change of hundred seed weight was found to be high, $7.26 \%$, per year or $297.7 \%$ over 43 years period (Table 5). The estimated annual rate of changes was in the same direction with that of all other traits; however, it was significant $(b=0.738)$, as it was not observed for plant height (Table 4). This result was in agreement with finding of other similar works which found positive change in hundred seed weight (Bezawuletaw et al., 2006; Hagos et al., 2012; Tolessa et al., 2015). This change of hundred seed weight may be attributed to reduction of yield potential from optimum level. On the other hand, there were indications of 100 seed weight increment in kabuli chickpea cultivars over the period of the study (Figure 2), which indicates that further improvement is possible to increase this trait and this provides clues for breeders to exploit (increase) the hundred seed weight and other traits of the existing kabuli chickpea varieties.

\subsection{Correlation Analysis}

Grain yield was significantly and positively $(\mathrm{P} \leq 0.05)$ associated with days to flowering $(\mathrm{r}=0.65)$ but showed no significant association with days to maturity $(r=0.25)$, plant height $(r=0.22)$ and 100 seed weight $(r=-0.05)$ (Table 6). It was observed that grain yield was significantly and positively related with number of pods per plant in their study with soybean (Faisal et al., 2006). Highly significant correlation between the number of seeds per pod and the number of pods per plant have been reported for chickpea grain yield (Savitha, 2008), which indicates that these characters can contribute to yield increment.

In this study, significant and positive relationship was obtained for seed yield and days to flowering. Contrary to the present result, no association was recorded for seed yield with days to flowering on teff (Teklu, 1998) and haricot bean (Bezawuletaw et al., 2006). Similarly, it was shown that yield was negatively correlated with days to 50\% flowering (Faisal et al., 2006; Hagos et al., 2012; Ramteke et al., 2010). In soybean seed yield and days to flowering didn't show correlation but positive association (Salado-Navarro et al., 1993). The lack of relationship between grain yield and days to physiological maturity (Table 6) observed herein supported the findings on tef (Teklu, 1998). On the other hand, in other studies it was reported that there was positive association for grain yield with days to physiological maturity (Laing et al., 1984; Salado-Navarro et al., 1993); as opposed to significantly negative association obtained between the same in wheat (Waddington et al., 1987). Bezawuletaw et al. (2006) also found that no correlation between grain yield and days to maturity. In contrary, negative but significant relationship between yield and days to maturity was reported on groundnut (Hagos et al., 2012).

No associate between seed yield and plant height (Table 6) observed in the current study was in agreement with results of other similar study on haricot bean (Bezawuletaw et al., 2006). Contrary to present finding, Riggs et al. (1981) reported positive association in wheat and negative association in spring barley, respectively, between grain yield and harvest index. As shown in Table 6, insignificant association was found between seed yield and 
100 seed weight $(\mathrm{r}=-0.05, \mathrm{p}>0.05)$. Similarly, several authors also observed no association between chickpea seed yield and 100 seed weight (Bezawuletaw et al., 2006; Riggs et al., 1981; Tarekegne, 1994; Teklu, 1998; Waddington et al., 1987; White \& Izquierdo, 1991). In contrast, positive correlation were recorded for grain yield with the number of seeds per pod and mean hundred seed weight in soybean (Hagos et al., 2012; Karmakar \& Bhatanagar, 1996), with the number of seed per year in wheat crop.

Table 6. Correlation coefficients of mean values of yield and yield related traits of Kabuli chickpea varieties represented in the study

\begin{tabular}{llllll}
\hline Character & Grain yield & Days to flowering & Days to maturity & Plant height & 100 Seed weight \\
\hline Grain yield & - & & & & \\
Days to flowering & $0.6538^{* *}$ & - & & & \\
Days to maturity & 0.2450 & 0.5708 & - & - \\
Plant height $(\mathrm{cm})$ & 0.2154 & 0.5693 & 0.5168 & 0.0837 & - \\
100 seed weight $(\mathrm{g})$ & -0.0521 & -0.4303 & -0.1763 & \\
\hline
\end{tabular}

Note. ${ }^{* *}=$ Significant at $\mathrm{P} \leq 0.05$.

Only days to flowering were positively and significantly $(\mathrm{P} \leq 0.05)$ associated with grain yield (Table 6). In contrast, it was reported that yield was negatively associated with days to $50 \%$ flowering and days to maturity (Ramteke et al., 2010). Faisal et al. (2006) also found negative association of grain yield of soybean with days to $50 \%$ flowering, days to flowering completion and days to maturity. This indicates that selection on the basis of these traits might lead to kabuli chickpea yield loss for early maturing kabuli chickpea varieties and yield gain for late maturing varieties. Thus, days to $50 \%$ flowering, days to maturity and plant height had positive association with grain yield of kabuli chickpea varieties. Maximum associations were observed for days to flowering and grain yield $(r=0.65)$ followed by days to maturity $(r=0.25)$ and plant height $(r=0.22)$.

Despite insignificant increase of regression coefficient $(P \leq 0.05, b=0.14)$ of days to flowering over the 43 years (Table 4), a positive and significant $(\mathrm{P}>0.05)$ correlation was observed between days to flowering and grain yield (Table 6). Contrary to the present result, it was indicated that the genetic association of days to flowering with grain yield was negative and significant (Ramteke et al., 2010). Kabuli chickpea varieties have shown a significant $(\mathrm{P} \leq 0.05)$ and positive association between grain yield and days to flowering (Table 6), but the regression coefficient $(b=0.738)$ indicated that there was significant trend for hundred seed weight from the older to the newest variety. The present study has also shown a non-significant $(\mathrm{P}>0.05)$ and positive correlation between days to flowering and days to maturity and plant height. Hundred seed weight has negative association with both days to flowering and maturity but has positive association with plant height (Table 6). Hence, based on the findings of the present study, it could be concluded that genetic yield potential improvement program of kabuli chickpea varieties over the last 43 years has been mostly correlated with a corresponding increase of days to flowering. This principal yield component was positively associated with days to maturity and plant height as well (Table 6).

\section{Conclusions}

During the period 1974 to 2017, substantial progress was made in improving the seed yield potential of kabuli chickpea. Moreover, changes occurred on the correlated morphophysiological characters parallel to varietal release. The results of this study show that there was significant increase in the seed yield potential of kabuli chickpea through consecutive release of varieties over the last 43 years. The response of hundred seed weight to past kabuli chickpea breeding efforts in Ethiopia was far better than that of seed yield. The change in genetic gain from breeding kabuli chickpea for hundred seed weight, may be attributed to reduction of grain yield. The present study also revealed that the genetic yield potential improvement of kabuli chickpea over the last 43 years was significantly associated only with paralleled increases in days to flowering. However, this trait hand less response to breeding than grain yield. It is, therefore, advisable that breeding efforts in the future variety development program should also give due attention to yield related traits and disease resistant kabuli chickpea varieties. 


\section{Acknowledgements}

The authors thank staff members of Chickpea Crop Improvement Program of Debre Zeit Agricultural Research Center (DZARC) for provision of the data on chickpea varieties. The financial support provided by Regional University Forum for Capacity Building in Agriculture (RUFORUM) and the Bill and Melinda Gates Foundation through the Tropical Legumes III project coordinated by International Crop Research Institute for the Semi-Arid Tropics (ICRISAT) is also dully acknowledged.

\section{References}

Bezawuletaw, K., Ketema, B., \& Prapa, S. (2006). Genetic gain in grain yield potential and associated agronomic traits in haricot bean (Phaseolus vulgaris L.). Kasetsart J Nat Sci, 40, 835-847.

Brancourt-Hulmel, M., Doussinault, G., Lecomte, C., Bérard, P., Le Buanec, B., \& Trottet, M. (2003). Genetic improvement of agronomic traits of winter wheat cultivars released in France from 1946 to 1992. Crop Science, 43, 37-45. https://doi.org/10.2135/cropsci2003.3700

Cox, T. S., Shroyer, J. P., Ben-Hui, L., Sears, R. G., \& Martin, T. J. (1988). Genetic improvement in agronomic traits of hard red winter wheat cultivars 1919 to 1987. Crop Science, 28, 756-760. https://doi.org/10.2135/ cropsci1988.0011183X002800050006x

CSA. (2015). The 2015 National statistics Agriculture.

Demissew, T. (2010). Genetic gain in grain yield and associated traits of early and medium maturing varieties of soybean (MSc. Thesis, School of Plant Sciences, Haramaya University).

EARO. (2000). National crop research strategy (p. 52). Ethiopian Agricultural Research Organization, Addis Ababa, Ethiopia.

Ercan, R. H., Koksel, A., \& Dag, A. (1995). Cooking quality and composition of chickpea grown in Turkey. Gida, 20, 289-293.

Evans, L. T. (1993). Crop evolution, adaptation and yield. Cambridge University Press: New York.

Faisal, M., A., M., Qureshi, A. S., Ashraf, M., \& Ghafoor, A. (2006). Genetic variability of the main yield related characters in Soybean. International Journal of Agriculture and Biology, 8, 815-819.

FAOSTAT. (2014). Bulletin of Statistics. Food and Agricultural Organization (FAO). Retrieved from http://faostat.org/faostatcoll ectionsubset = agriculture

Fekadu, W., Zeleke, H., \& Ayana, A. (2011). Genetic improvement in grain yield potential and associated traits of food barley (Hordeum vulgare L.) in Ethiopia. Ethiop. J. Appl. Sci. Technol., 2, 43-60.

Gowda, C. L. L., Upadhyaya, H. D., Dronavalli, N., \& Singh, S. (2010). Identification of Large-Seeded High-Yielding Stable Kabuli Chickpea Germplasm Lines for Use in Crop Improvement. Crop Science, 51(1), 198-209. https://doi.org/10.2135/cropsci2010.01.0078

Hagos, F., Habtamu, Z., \& Bulcha, W. (2012). Genetic Gain in Yield and Yield Related Traits of Desi Chickpea (Cicer arietinum L.) in Centeral Rift Valley of Ethiopia. East African Journal of Sciences, 6, 125-136.

Jin, J., Liu, X., Wang, G., Mi, L., Shen, Z., Chen, X., \& Herbert, S. J. (2010). Agronomic and physiological contributions to the yield improvement of soybean cultivars released from 1950 to 2006 in Northeast China. Field Crops Research, 115, 116-123. https://doi.org/10.1016/j.fcr.2009.10.016

Karmakar, P. G., \& Bhatanagar, P. S. (1996). Genetic improvement of soybean varieties released in India from 1969-1993. Euphytica, 90, 95-103.

Keneni, G., Bekele, E., Imtiaz, M., Getu, E., Dagne, K., \& Assefa, F. (2011). Breeding chickpea (Cicer arietnum [Fabaceae]) for better seed quality inadvertently increased susceptibility to adzuki bean beetle (Callosobruchus chinensis [Coleoptera: Bruchidae]). International Journal of Tropical Insect Science, 31, 249-261. https://doi.org/10.1017/S1742758411000373

Laing, D. R., Jones, P. G., \& Davis, J. H. (1984). Common bean (Phaseolus vulgaris L.). In P. R. Goldsworthy \& N. M. Fisher (Eds.), The Physiology of Tropical Field Crops (pp. 305-351). John Wiley, New York.

Liu, G., Yang, C., Xu, K., Zhang, Z., Li, D., Wu, Z., \& Chen, Z. (2012). Development of yield and some photosynthetic characteristics during 82 years of genetic improvement of soybean genotypes in northeast China. Australian Journal of Crop Science, 6, 1416-1422. 
Luque, S. F., Cirilo, A. G., \& Otegui, M. E. (2006). Genetic gains in grain yield and related physiological attributes in Argentine maize hybrids. Field Crops Research, 95, 383-397. https://doi.org/10.1016/ j.fcr.2005.04.007

Martintello, P., Delocu, G., Boggini, G., Odoardi, M., \& Stanca, A. M. (1987). Breeding progress in grain yield and selected agronomic characters of winter barley (Hordeum vulgare L.) over the last quarter of a century. Plant Breeding, 99, 289-294. https://doi.org/10.1111/j.1439-0523.1987.tb01184.x

Morrison, M. J., Voldeng, H. D., \& Cober, E. R. (2000). Agronomic changes from 58 years of genetic improvement of short-season soybean cultivars in Canada. Agronomy Journal, 92, 780-784. https://doi.org/ 10.2134/agronj2000.924780x

Mozingo, R. W., Coffelt, T. A., \& Wynne, J. C. (1987). Genetic improvement in large-seeded Virginia-type peanut cultivars since 1944. Crop Science, 27, 228-231. https://doi.org/10.2135/cropsci1987.0011183X00 2700020020x

Parveen, L., \& Khalil, I. J. (2011). Improvement of agronomic traits in spring wheat cultivars released in NWFP during 1958 to 2000. Sarhad J. Agric., 27, 51-57.

Pereira, M. L., Sadras, V. O., \& Trápani, N. (1999). Genetic improvement of sunflower in Argentina between 1930 and 1995. I. Yield and its components. Field Crops Research, 62, 157-166. https://doi.org/10.1016/ S0378-4290(99)00015-5

Perry, M. W., \& D’Antuono, M. F. (1989). Yield improvement and associated characteristics of some Australian spring wheat cultivars introduced between 1960 and 1982. Australian Journal of Agricultural Research, 50, 457-472.

Ramteke, R., Kumar, M. V., \& Agarwal, D. K. (2010). Study on genetic variability and traits interrelationship among released soybean varieties of India [Glycine max (L.) Merrill]. Electronic Journal of Plant Breeding, $1,1483-1487$.

Riggs, T. J., Hanson, P. R., Start, N. D., Miles, D. M., Morgn, C. L., \& Dord, M. A. (1981). Comparison of spring barley varieties grown in England and Wales between 1880 and 1980. Journal of Agricultural Science, 97, 599-610. https://doi.org/10.1017/S0021859600036935

Rodrigues, O., Lhamby, J. C. B., Didonet, A. D., \& Marchese, J. A. (2007). Fifty years of wheat breeding in Southern Brazil: Yield improvement and associated changes. Pesquisa Agropecuária Brasileira, 42, 817-825. https://doi.org/10.1590/S0100-204X2007000600008

Salado-Navarro, L. R., Sinclair, T. R., \& Hinson, K. (1993). Changes in seed yield and seed growth traits in soybean cultivars released in southern USA from 1945 to 1983. Crop Science, 33, 1204-1209. https://doi.org/10.2135/cropsci1993.0011183X003300060019x

Savitha, B. N. (2008). Characterization of Avare [Lablab purpureus (L.) Sweet] Local Collections for Genetic Variability (MSc. Thesis presented to the University of Agricultural Sciences, Dharwad).

Shearman, V. J., Sylvester-Bradley, R., Scott, R. K., \& Foulkes, M. J. (2005). Physiological processes associated with wheat yield progress in the UK. Crop Science, 45, 175-185.

Specht, J. E., \& Williams, J. H. (1984). Contribution of genetic technology to soybean productivity-Retrospect and prospect. Genetic contributions to yield gains of five major crop plants (pp. 49-74). Crop Science Society of America and American Society of Agronomy.

Tarekegne, A. (1994). Yield Potential of Rainfed Wheat in the Central Highlands of Ethiopia (MSc. Thesis, Alemaya Universityof Agriculture, Alemaya, Ethiopia).

Tefera, H., Kamara, A. Y., Asafo-Adjei, B., \& Dashiell, K. E. (2009). Improvement in grain and fodder yields of early-maturing promiscuous soybean varieties in the Guinea Savanna of Nigeria. Crop Science, 49, 2037-2042. https://doi.org/10.2135/cropsci2009.02.0081

Teklu, Y. (1998). Genetic Gain in Grain Yield Potential and Associated Agronomic Traits of Tef [Eragrostis tef (Zuss) Trotter] (MSc. Thesis. Alemaya University of Agriculture Alemaya, Ethiopia).

Tolessa, T., Keneni, G., \& Mohammad, H. (2015). Genetic progresses from over three decades of faba bean (Vicia faba L.) breeding in Ethiopia. Australia Journal of Crop Science, 9, 41-48.

Ustun, A., Allen, F. L., \& English, B. C. (2001). Genetic progress in soybean of the US Midsouth. Crop Science, 41, 993-998. https://doi.org/10.2135/cropsci2001.414993x 
Voldeng, H. D., Cober, E. R., Hume, D. J., Gillard, C., \& Morriso, M. J. (1997). Fifty-eight years of genetic improvement of short-season soybean cultivars in Canada. Crop Science, 37, 428-431. https://doi.org/ 10.2135/cropsci1997.0011183X003700020020x

Waddington, S. R., Osmanzai, M., Yoshida, M., \& Ransom, J. K. (1987). The yield of durum wheats released in Mexico between 1960 and 1984. The Journal of Agricultural Science, 108, 469-477. https://doi.org/ $10.1017 / \mathrm{S} 002185960007951 \mathrm{X}$

White, J. W., \& Izquierdo, J. (1991). Physiology of yield potential and stress tolerance. In A. Van Schoonhoven \& O. Voysest (Eds.), Common Bean: Research for Crop Improvement (pp. 287- 382). CAB International. Nillingford, UK.

Worku, M., \& Zelleke, H. (2007). Advances in improving harvest index and grain yield of maize in Ethiopia. East African Journal of Science, 1, 112-119. https://doi.org/10.4314/eajsci.v1i2.40349

\section{Copyrights}

Copyright for this article is retained by the author(s), with first publication rights granted to the journal.

This is an open-access article distributed under the terms and conditions of the Creative Commons Attribution license (http://creativecommons.org/licenses/by/4.0/). 